\title{
ESTIMATION OF THE ALLOWABLE CONCENTRATION OF CHLORIDES IN SOAKING EFFLUENTS FROM THE TANNING PROCESS USING ECOTOXICOLOGICAL TOOLS
}

\author{
Ruth MOGOLLON ROPA, Liliana MARRUFO SALDAÑA*, Julio BARRA HINOJOSA*, Rosa CONTRERAS PANIZO, \\ Robert BULEJE DEL CARPIO \\ Productive Innovation and Technological Transfer Center of Leather, Footwear and related industries (CITEccal Lima). \\ Technological Institute of Production (ITP), Caquetá Ave. 1300, Rímac, 15094, Lima, Perú, rmogollonr@uni.pe, \\ Imarrufo@itp.gob.pe, julio.barra.h@uni.pe,rcontreras@itp.gob.pe,rbuleje@itp.gob.pe
}

Received: 19.06 .2020

Accepted: 15.10 .2020

https://doi.org/10.24264/Ifj.20.4.6

ESTIMATION OF THE ALLOWABLE CONCENTRATION OF CHLORIDES IN SOAKING EFFLUENTS FROM THE TANNING PROCESS USING ECOTOXICOLOGICAL TOOLS

ABSTRACT. The use of sodium chloride for the preservation of pelts and skins destined for tanning is a very widespread technique in Peru, therefore the quantities used of this salt represent high concentrations of chlorides in the liquid effluents that are generated, which can affect the environmental quality of ecosystems and human health. The present study aimed to estimate an allowable concentration of chlorides in tanning effluents using ecotoxicological tools so that it would serve as a guide for the tanning industry and the authorities in their efforts to establish better conservation practices and effluent control parameters, which are currently absent from national environmental legislation. The permissible concentration of chlorides was determined using bioassays with seeds of Lactuca sativa species (lettuce), which was exposed to soaking effluents obtained from local tanneries. The studied species was determined based on sensitivity tests to zinc sulfate $\left(\mathrm{ZnSO}_{4}\right)$ applied to three commercial lettuce species. The selected lettuce seed presented a germination rate higher than $90 \%$, a CV lower than $30 \%$ and an IC $\mathrm{C}_{50}$ of $38.97 \mathrm{mg} / \mathrm{L}$ of $\mathrm{Zn}^{+2}$ with a confidence interval between $19.30 \mathrm{mg} / \mathrm{L}$ and $58.65 \mathrm{mg} / \mathrm{L}$ of $\mathrm{Zn}{ }^{+2}$. The admissible guide concentration determined for chlorides in soaking effluents from $\mathrm{IC}_{50}$ was $582.30 \mathrm{mg} / \mathrm{L}$ with a minimum value of $258.45 \mathrm{mg} / \mathrm{L}$ and a maximum of 906.15 $\mathrm{mg} / \mathrm{L}$. Additionally, because of the presence of other pollutants in the soaking effluents, such as bactericides, organic matter, enzymes and salts added in soaking process, tests with synthetic solutions of sodium chloride at the same concentrations of the soaking effluents were conducted, to evaluate the effect produced by those substances.

KEY WORDS: waste valorization, chrome shavings, alkaline hydrolysis, tanning process

\section{ESTIMAREA CONCENTRAṬIEI ADMISIBILE DE CLORURI ÎN EFLUENȚII DE LA ÎNMUIERE DIN CADRUL PROCESULUI DE TĂBĂCIRE FOLOSIND} INSTRUMENTE ECOTOXICOLOGICE

REZUMAT. Utilizarea clorurii de sodiu pentru conservarea blănurilor și a pieilor pentru tăbăcire este o tehnică foarte răspândită în Peru, prin urmare cantitățile de sare utilizate înseamnă concentrații mari de cloruri în efluenții generați, ceea ce poate afecta calitatea ecologică a ecosistemelor și sănătatea umană. Prezentul studiu are ca scop estimarea concentrației admisibile de cloruri în efluenții de la tăbăcire utilizând instrumente ecotoxicologice, astfel încât să servească drept ghid pentru industria de pielărie și pentru autorități în eforturile acestora de a stabili practici mai bune de conservare și parametrii de control al efluenților, care lipsesc în prezent din legislația națională de mediu. Concentrația admisibilă de cloruri a fost determinată folosind teste biologice cu semințe din specia Lactuca sativa (salată), care au fost expuse la efluenții de înmuiere obținuți din tăbăcăriile locale. Specia studiată a fost determinată pe baza testelor de sensibilitate la sulfatul de zinc $\left(\mathrm{ZnSO}_{4}\right)$ aplicate la trei specii de salată comercială. Semințele de salată selectate au prezentat o rată de germinare mai mare de $90 \%$, un coeficient de variație (CV) mai mic de $30 \%$ și o concentrație inhibitorie maximă $50 \%$ (IC ${ }_{50}$ ) de $38,97 \mathrm{mg} / \mathrm{I}$ de $\mathrm{Zn}^{\text {+2 }}$ cu un interval de încredere între 19,30 mg/l și 58,65 mg/l de Zn+2. Concentrația orientativă admisă determinată pentru cloruri în efluenții de înmuiere la $I_{50}$ a fost de $582,30 \mathrm{mg} / \mathrm{l}$ cu o valoare minimă de $258,45 \mathrm{mg} / \mathrm{I} \mathrm{și} \mathrm{maxim} \mathrm{de} 906,15 \mathrm{mg} / \mathrm{l}$. În plus, din cauza prezenței altor poluanți în efluenții de înmuiere, cum ar fi bactericidele, materia organică, enzimele și sărurile adăugate în procesul de înmuiere, s-au efectuat teste cu soluții de clorură de sodiu sintetică la aceleași concentrații ale efluenților de înmuiere, pentru a evalua efectul produs de aceste substanțe.

CUVINTE CHEIE: valorificarea deșeurilor, răzătură de piele cromată, hidroliză alcalină, proces de tăbăcire

\section{ESTIMATION DE LA CONCENTRATION ADMISSIBLE DE CHLORURES DANS LES EFFLUENTS DE TREMPAGE DU PROCESSUS DE TANNAGE À} L'AIDE D'OUTILS ÉCOTOXICOLOGIQUES

RÉSUMÉ. L'utilisation de chlorure de sodium pour la conservation des fourrures et des peaux destinées au tannage est une technique très répandue au Pérou, donc les quantités utilisées de ce sel représentent des concentrations élevées de chlorures dans les effluents liquides générés, ce qui peut affecter la qualité environnementale des écosystèmes et la santé humaine. La présente étude visait à estimer une concentration admissible de chlorures dans les effluents de tannage à l'aide d'outils écotoxicologiques afin qu'elle serve de guide à l'industrie du tannage et aux autorités dans leurs efforts pour établir de meilleures pratiques de conservation et des paramètres de contrôle des effluents, qui sont actuellement absents de législation environnementale nationale. La concentration admissible de chlorures a été déterminée à l'aide d'essais biologiques avec des graines d'espèces de Lactuca sativa (laitue), qui ont été exposées à des effluents de trempage provenant de tanneries locales. L'espèce étudiée a été déterminée sur la base de tests de sensibilité au sulfate de zinc $\left(\mathrm{ZnSO}_{4}\right)$ appliqués à trois espèces de laitues commerciales. La graine de laitue sélectionnée présentait un taux de germination supérieur à $90 \%$, un coefficient de variation (CV) inférieur à $30 \%$ et une concentration inhibitrice médiane $\left(\mathrm{Cl}_{50}\right)$ de $38,97 \mathrm{mg} / \mathrm{L}$ de $\mathrm{Zn}^{+2}$ avec un intervalle de confiance entre 19,30 mg/L et

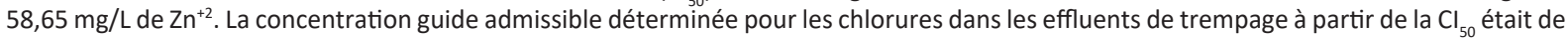
$582,30 \mathrm{mg} / \mathrm{L}$ avec une valeur minimale de $258,45 \mathrm{mg} / \mathrm{L}$ et un maximum de $906,15 \mathrm{mg} / \mathrm{L}$. De plus, en raison de la présence d'autres polluants dans les effluents de trempage, tels que les bactéricides, la matière organique, les enzymes et les sels ajoutés dans le processus de trempage, des essais avec des solutions synthétiques de chlorure de sodium aux mêmes concentrations des effluents de trempage ont été effectués, pour évaluer l'effet produit par ces substances.

MOTS CLÉS : valorisation des déchets, copeaux de cuir chromé, hydrolyse alcaline, procédé de tannages

\footnotetext{
* Correspondence to: Liliana MARRUFO SALDAÑA and Julio BARRA HINOJOSA, Productive Innovation and Technological Transfer Center of Leather, Footwear and related industries (CITEccal Lima). Technological Institute of Production (ITP), Caquetá Ave. 1300, Rímac, 15094, Lima, Perú,Imarrufo@itp.gob.pe, julio.barra.h@uni.pe.
} 


\section{INTRODUCTION}

The tanning industry generates pollutants with significant dangerous effects on the environment because traditional leather processing procedures involve large amounts of chemicals and water throughout their different stages $[1,2]$. In the beamhouse operations, the initial stage, more water is needed than in any of the other stages because the skins that have previously gone through a conservation process have to be re-hydrated; this conservation is carried out with layers of salt (sodium chloride) to avoid its natural decomposition $[3,4]$ and consequently the effluents generated in this stage presents large amounts of sodium chloride $(\mathrm{NaCl})$ which, if spilled into the environment, can cause damage to the soil and even impact waterbodies, altering the normal development of the living organisms that inhabit them [2].

Different studies had been carried out to evaluate the toxicity of tannery effluents; Hussain et al. [5] analyzed the effect of tannery effluents on seeds germination and growth of two sunflower cultivars in Pakistan, their results showed that the raw effluent caused the reduction in biomass accumulation and reproductive growth of sunflower cultivars, and that one of them was more resistant to lower concentrations, but due to the presence of chemicals, the effluents are not suitable for inclusion in irrigation system. Calheiros et al. [6] tested tannery effluents with high salinity treated by an activated sludge system on the germination and seedling growth of red clover (Trifolium pretense), where growth was inhibited by concentrations over $25 \%$ and undiluted effluent caused a complete germination inhibition. Kohli and Malaviya [7] evaluated the impact of tannery effluents with high salinity $(45.97 \mathrm{ppm})$ at different concentrations on the germination pattern of ten varieties of wheat (Triticum aestivum), where some varieties exhibited more tolerance at lower concentrations of tannery effluents, showing a potential to grow in tannery effluents contaminated soils.

Currently, Peru has environmental legislation for the regulation of physical and chemical parameters in the effluents generated by the tanning industry. However, despite the harmful consequences that high concentrations of chlorides on waterbodies can generate
[8], this parameter is not being regulated, and when a tannery treats its effluents, they don't know how much this parameter must be reduced to establish its treatment level. One of the methods used for stablishing maximum allowable concentrations is the use of bioassays $[9,10]$, where the toxicity of an effluent sample is tested by measuring its effect on the growth of bioindicators organisms; in view of this, the present study aimed at proposing a maximum allowable concentration of chlorides, supported on the basis of toxicity bioassays with seeds of Lactuca sativa species exposed to local tannery effluents to determine the half maximal inhibitory concentration (IC50) [11, 12]. Likewise, the toxicity of synthetic samples of sodium chloride was evaluated to determine the effect of other substances from the soaking process. The analysis of the bioassay results was done by the statistical complement REAL STATISTICS, ANOVA tests and multiple comparisons.

\section{EXPERIMENTAL}

\section{Materials and Methods}

Sample

The tanning effluents used in this research corresponded to those generated in the soaking phase of the tanning processes of local tanneries in the city of Lima. The samples were kept at a temperature below $4 \stackrel{\circ}{\circ}$, immediately after being taken.

\section{Determination of Chloride Concentration in Effluents}

The determination of the concentration of chlorides in $\mathrm{mg} / \mathrm{L}$ in the soaking effluent was carried out in a laboratory accredited by INACAL using the EPA 300.0 method. Rev. 2.1:1993. Determination of Inorganic Anions by Ion Chromatography.

Toxicity Test

The toxicity tests were carried out in the R\&D Laboratory of the Center for Productive Innovation and Technology Transfer of the Leather, Footwear and Related Industries (CITEccal Lima) and included the application of sensitivity tests for the selection of the test 
species from commercial Lactuca sativa seeds $[11,13,14]$, the toxicity analysis of soaking effluents and synthetic samples of sodium chloride with the selected seed.

The chemical reagents used were sodium bicarbonate for analysis ACS, Reag. Ph Eur MERCK, magnesium sulfate heptahydrate for analysis EMSURE ${ }^{\circledR}$ ACS, Reag. Ph Eur MERCK, potassium chloride for analysis Reag. Ph Eur SCHARLAU for the preparation of the reconstituted water. Anhydrous zinc sulfate, brand name, for the sensitivity test. As for the equipment, an analytical balance AND, model GF-1000 was used; an oven JP SELECTA, model DRY - BIG and an incubator VELP, model FTC 90I; all calibrated. In all procedures, reconstituted water was used and the materials used were washed with neutral detergent, EXTRAN, rinsed with tap water and distilled water. The volumetric glass materials were dried in an oven at a temperature not exceeding $50^{\circ} \mathrm{C}$ and the petri dishes were dried at a temperature of $100^{\circ} \mathrm{C}$ to sterilize them.

The reconstituted water was prepared with distilled water and had a composition of $192 \mathrm{mg} / \mathrm{L}$ of sodium bicarbonate, $120 \mathrm{mg} / \mathrm{L}$ of anhydrous magnesium sulfate and $8 \mathrm{mg} / \mathrm{L}$ of potassium chloride. The stock solution of zinc sulfate had a concentration of $500 \mathrm{mg} / \mathrm{L}$ from which the following concentrations were obtained by dilution with reconstituted water: $8.15 \mathrm{mg} / \mathrm{L}, 16.30 \mathrm{mg} / \mathrm{L}, 32.40 \mathrm{mg} / \mathrm{L}, 48.89$ $\mathrm{mg} / \mathrm{L}$ and $65.19 \mathrm{mg} / \mathrm{L}$. The synthetic samples of sodium chloride were prepared from a $28.57 \mathrm{~g} / \mathrm{L}$ chloride stock solution using reconstituted water as the solvent.

The selection of the species for the toxicity tests was made from the study of red lettuce seeds from the Hydroponics Unit of the National Agrarian University La Molina (UNALM), romaine lettuce seeds from the bio garden of the UNALM and long light green romaine lettuce seeds, butter variety, from BATLLE S.A. 08750 Molins de Rei, Barcelona, Spain. Seeds were exposed to reconstituted water and to the diluted concentrations of the $\mathrm{ZnSO}_{4}$ stock solution, being determined for each of them the germination percentage, the coefficient of variation between the replicates and the $\mathrm{IC}_{50}$.

After the selection of the test organism, the $\mathrm{IC}_{50}$ of the tanning effluents was determined by exposing them to tanning effluent dilutions corresponding to $1 \%, 3 \%, 10 \%, 30 \%$ and $100 \%$ prepared with reconstituted water. The exposure of the seed to the synthetic sodium chloride solution was made from dilutions of the stock solution corresponding to $285.7 \mathrm{mg} / \mathrm{L}, 857.1$ $\mathrm{mg} / \mathrm{L}, 2857.1 \mathrm{mg} / \mathrm{L}, 8571.4 \mathrm{mg} / \mathrm{L}, 28$ 571, 4 $\mathrm{mg} / \mathrm{L}$.

The procedure of exposing the seeds to reconstituted water, stock solution dilutions and effluent dilutions was initiated by placing filter paper discs on the plates, then using a pipette to saturate each of the plates with $2 \mathrm{~mL}$ of the solutions to prevent air bubbles. Later, using a tweezer, 20 seeds were carefully placed in each plate, leaving enough space between the seeds to allow the elongation of the roots. The plates were then covered and placed in plastic bags to prevent them from losing humidity, and finally they were placed in the incubator for 120 hours (5 days) at a temperature of $22 \pm 2 \circ \mathrm{C}$. Each concentration or dilution was worked in triplicate $[10,15,16]$.

For all cases the final evaluation consisted of comparing the effects generated in the test organisms exposed to the sample (zinc sulphate, soaking effluent and synthetic sodium chloride sample) with the response of the exposed organisms to the negative control (reconstituted water) under the same test conditions. Once the exposure period was completed (120 hours), the effect on germination and elongation of the radicle was quantified. Samples with necrosis, fungi or other aspects that may have interfered with germination and growth were observed. Seed elongation was performed by measuring root growth.

The germination percentage (GP) was determined by comparing the sown seeds with the germinated ones according to the following equation:

$$
G P(\%)=\frac{\text { Number of total germinated seeds }}{\text { Total number of seeds tested }} \times 100
$$



The radicle growth inhibition percentage elongation for each dilution with respect to the (RIGP) was estimated with the average average elongation of the negative control.

$$
\operatorname{RIGP}(\%)=\left(\frac{\bar{x} \text { elongation at dilution } \tau-\bar{x} \text { control elongation }}{\bar{x} \text { control elongation }}\right) \times 100
$$

The half maximal inhibitory concentration $\left(\mathrm{IC}_{50}\right)$ is the concentration where the $50 \%$ of the test organisms are inhibited, in this study, where the elongation of the radicle is inhibited at $50 \%$. The $I C_{50}$ was determined on the basis of a fitting equation with a regression coefficient greater than $80 \%$ which is derived from the graph of the percentage inhibition vs. the diluted concentrations of the samples (dose-response curve). From the fitting equation:

$$
\begin{gathered}
y=a x+b, \text { with } R^{2}>0.8 \\
x=C I 50 \text { when } y=50 \% \text {, then } C I 50=\frac{50-b}{a}
\end{gathered}
$$

Where:

$x$ : Dilution

$y$ : Radicle growth inhibition percentage (RIGP)

The coefficient of variation (CV) was determined by determining the elongation standard deviation of a series of measurements between the average elongations.

$$
C V(\%)=\left(\frac{\text { standard deviation of elongation data }}{\text { Average elongation }}\right) \times 100
$$

For the statistical analysis of the results, the analysis of the normality of the data for each dilution with the Shapiro Wilk test was considered. Likewise, by means of an ANOVA analysis and multiple comparison tests through Tukey Test and Dunnett Test, it was evaluated if there were significant differences between the sample dilutions of each toxicity test with the negative control and between the dilutions. This analysis was performed with the supplement Real Statistics for MS. Excel.

\section{RESULTS AND DISCUSSIONS}

\section{Evaluation of the Seeds}

Table 1 shows the germination results for the three species evaluated. The highest average percentage of germination in reconstituted water corresponds to light green romaine lettuce with a value of $93.89 \%$. On the other hand the lowest average value for the coefficient of variation, also corresponds to this species and is equal to $24.53 \%$ according to the methodology of Acute Toxicity Test with seeds of Lactuca sativa L. $[10,17]$ it is considered that there is a good percentage of germination if this is greater or equal to $90 \%$ and an adequate $\mathrm{CV}$ if this is less or equal to $30 \%$. 
Table 1: Comparison between the results of percentage of germination, coefficient of variation and $\mathrm{Cl} 50$ for the species of lettuce studied

\begin{tabular}{cccccccccc}
\hline & \multicolumn{3}{c}{ Red lettuce } & \multicolumn{4}{c}{ Romaine lettuce } & \multicolumn{3}{c}{ Light green romaine lettuce } \\
Day & $\begin{array}{c}\% \text { of } \\
\text { germination }\end{array}$ & Root CV & $\begin{array}{c}\mathrm{IC}_{50} \\
(\mathrm{mg} / \mathrm{L})\end{array}$ & $\begin{array}{c}\text { \% of } \\
\text { germination }\end{array}$ & Root CV & $\begin{array}{c}\mathrm{IC}_{50} \\
(\mathrm{mg} / \mathrm{L})\end{array}$ & $\begin{array}{c}\% \text { of } \\
\text { germination }\end{array}$ & $\begin{array}{c}\text { Root } \\
\mathrm{CV}\end{array}$ & $\begin{array}{c}\mathrm{IC}_{50} \\
(\mathrm{mg} / \mathrm{L})\end{array}$ \\
\hline 01 & 70.00 & 33.38 & 95.87 & 55.00 & 48,35 & 82.79 & 91.67 & 29.07 & 121.77 \\
02 & 85.00 & 44.33 & 80.13 & 66.67 & 63.88 & 88.94 & 98.33 & 22.40 & 71.83 \\
02 & 65.00 & 34.24 & 45.63 & 88.33 & 38.95 & 42.57 & 91.67 & 22.12 & 56.03 \\
\hline
\end{tabular}

In terms of species sensitivity analysis, long light green romaine lettuce has the highest sensitivity expressed as an average $\mathrm{IC}_{50}$ of 48.07 $\mathrm{mg} / \mathrm{L}$. It should be noted that the correlation coefficients of the dose response curves were greater than 0.80 for all the trials, and in their determination the statistical conditions were met that there is normality in the data and significant differences between the concentrations or dilutions with the negative control and among themselves.

\section{Sensitivity Test - Positive Control}

Table 1 shows the germination results for the three species evaluated. The highest average percentage of germination in reconstituted water corresponds to light green romaine lettuce with a value of $93.89 \%$. On the other hand the lowest average value for the coefficient of variation, also corresponds to this species and is equal to $24.53 \%$ according to the methodology of Acute Toxicity Test with seeds of Lactuca sativa $L$. [10] it is considered that there is a good percentage of germination if this is greater or equal to $90 \%$ and an adequate $\mathrm{CV}$ if this is less or equal to $30 \%$.

To establish the reproducibility of the applied methodology, sensitivity tests were performed with the selected species from the following $\mathrm{Zn}$ (II) concentrations: $8.15 \mathrm{mg} / \mathrm{L}, 16.30 \mathrm{mg} / \mathrm{L}, 32.40 \mathrm{mg} / \mathrm{L}, 48.89$ $\mathrm{mg} / \mathrm{L}$ and $65.19 \mathrm{mg} / \mathrm{L}$. The $\mathrm{IC}_{50}$ of $\mathrm{Zn}$ (II) determined from root growth assessment was $38.97 \mathrm{mg} / \mathrm{L}$ with a $95 \%$ confidence interval between $19.30 \mathrm{mg} / \mathrm{L}$ and 58.65 $\mathrm{mg} / \mathrm{L}$. Figure 1 shows the established control chart for this test.

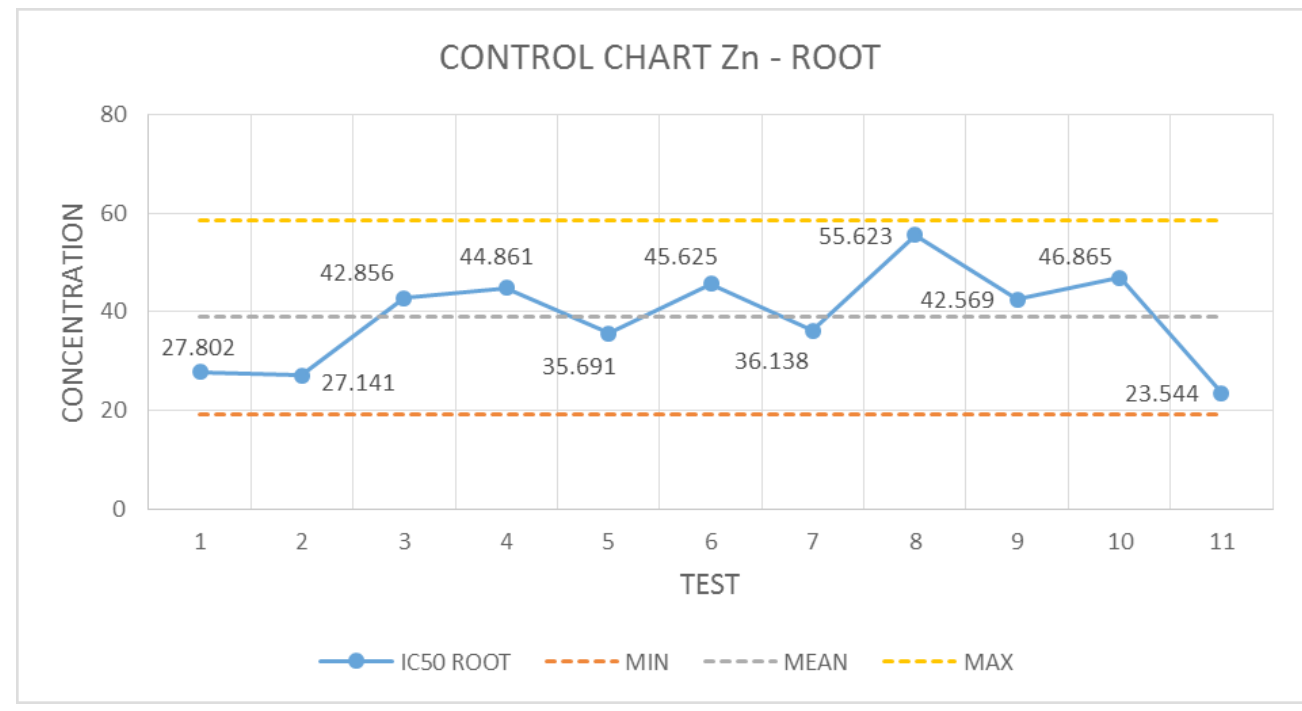

Figure 1. Control Chart Zn-Root 
Bohórquez P. and Campos C. [16] determined an $\mathrm{IC}_{50}$ for $L$. sativa of 24.48 $\mathrm{mg} / \mathrm{L}$ of $\mathrm{Zn}^{+2}$ with $95 \%$ confidence interval between $14.60 \mathrm{mg} / \mathrm{L}$ and $34.36 \mathrm{mg} / \mathrm{L}$.

Toxicity Tests on Soaking Effluents and Proposal of a Permissible Value for Chlorides in Tanning Effluents

Table 2 presents the results of the chloride concentration in soaking effluents from tanneries in Metropolitan Lima as well as the respective $\mathrm{IC}_{50}$ obtained in the toxicity tests. On average, an $\mathrm{IC}_{50}$ of $582.30 \mathrm{mg} / \mathrm{L}$ and a range with a minimum value of 258.45 $\mathrm{mg} / \mathrm{L}$ and a maximum value of $906.15 \mathrm{mg} / \mathrm{L}$ are determined. In order to determine the admissible concentration to be proposed, the safety factor or assessment factor approach was considered. This approach is applied to ensure the protection of the most sensitive organisms and is inversely proportional to the quantity and quality of the toxicity data available. However, when comparing the $\mathrm{IC}_{50}$ value obtained with the value of the Environmental Quality Standards for water in national legislation, which considers a value of $500 \mathrm{mg} / \mathrm{L}$ of chlorides for irrigation of vegetables and animal beverages (category 3 ) and with the value considered by international legislation for the case of Bogotá, which establishes a maximum value of chlorides in tanning effluents of $3,000 \mathrm{mg} / \mathrm{L}$, the conclusion was reached that the value of $582.30 \mathrm{mg} / \mathrm{L}$ of chloride is sufficiently restrictive to ensure that tanning effluents that come into contact with a water body do not affect the normal development of the species, therefore the safety factor applied was 1 .

Table 2: Chloride and IC $C_{50}$ concentration of soaking effluents from tanneries in Metropolitan Lima

\begin{tabular}{ccc}
\hline Sample code & $\begin{array}{c}\text { Chloride } \\
\text { concentration } \\
(\mathrm{mg} / \mathrm{L})\end{array}$ & $\mathrm{IC}_{50}(\mathrm{mg} / \mathrm{L})$ \\
\hline PC-11 & 9428.86 & 551.76 \\
PC-12 & 16578.55 & 477.08 \\
PC-13 & 9626.20 & 393.87 \\
PC-15 & 4082.95 & 695.29 \\
PC-16 & 16418.50 & 793.49 \\
\hline
\end{tabular}

Table 3: $I_{50}$ in synthetic samples of sodium chloride

\begin{tabular}{ccc}
\hline $\begin{array}{c}\text { Sample } \\
\text { code }\end{array}$ & $\begin{array}{c}\mathrm{IC}_{50}(\mathrm{mg} / \mathrm{L}) \text { for sodium } \\
\text { chloride in synthetic samples }\end{array}$ & $\begin{array}{c}\mathrm{IC}_{50}(\mathrm{mg} / \mathrm{L}) \text { for chloride } \\
\text { in synthetic samples }\end{array}$ \\
\hline 1 & 1040.59 & 631.23 \\
2 & 1688.22 & 1024.08 \\
3 & 1016.98 & 616.91 \\
\hline
\end{tabular}

Table 3 shows the $\mathrm{IC}_{50}$ values determined for synthetic sodium chloride samples. It can be seen that these values are higher than those obtained with the soaking effluent samples, this is because the synthetic sample does not contain other substances that normally result from a soaking effluent. The chemicals used in the soaking process are: sodium hydroxide, sodium hypochlorite, surfactants, bactericides and enzymatic preparations, these by their nature add to the final effluent a higher toxicity, on the other hand, besides salt, blood and dirt adhered to the skin are dragged away. This difference in toxicity would evidence the effect of salt in its pure and mixed state, which was also observed by Lyu et al. [18] who performed toxicity tests on Lactuca sativa L. with pure compounds and industrial effluent from Soyo and Daejeon in Korea, determining that the $\mathrm{Zn}$ concentration required to inhibit root elongation in $L$. sativa by $50 \%\left(\mathrm{IC}_{50}\right)$ was higher in Daejeon effluent than pure $\mathrm{Zn}$, concluding that $\mathrm{Zn}$ mixed with the 
effluent is less toxic than in pure form. Therefore, for the acceptable concentration to be proposed to be valid for the tanning industry, the joint effect of the chloride immersed in the soaking effluent should be considered. On the other hand, Campagna-Fernandes, Marin, \& Penha [12], determined that the effects of sodium chloride on root growth are detected from a concentration of $1,000 \mathrm{mg} / \mathrm{L}$ of $\mathrm{NaCl}$, that is, at $606,655 \mathrm{mg} / \mathrm{L}$ of $\mathrm{Cl}-$, values that coincide with those established in the present investigation.

\section{CONCLUSIONS}

The species of Lactuca sativa $L$. that validates the toxicity test is the long light green romaine lettuce, because it has a high percentage of germination (more than $90 \%$ ) that is preserved in time, a low variability of root elongation and hypocotyl (CV < $30 \%$ ) and presents the lowest values of $\mathrm{IC}_{50}$, that is to say, it is the most sensitive among those evaluated. The $\mathrm{IC}_{50}$ calculated by sensitivity tests with $\mathrm{ZnSO}_{4}$ for Lactuca sativa $L$. is $38.97 \mathrm{mg} / \mathrm{L}$ of $\mathrm{Zn}^{+2}$ with confidence interval between $19.30 \mathrm{mg} / \mathrm{L}$ and $58.65 \mathrm{mg} / \mathrm{L}$ of $\mathrm{Zn}^{+2}$. Analysis with synthetic samples of industrial sodium chloride led to the conclusion that chlorides have a more toxic effect if they are discharged to the environment as part of the steeping effluent than in their pure state, since the $\mathrm{IC}_{50}$ values of chlorides in synthetic samples were higher than the $\mathrm{IC}_{50}$ values of chlorides in steeping effluents.

The maximum allowable concentration of chlorides for soaking effluent determined in this work is $582.30 \mathrm{mg} / \mathrm{L}$ with a minimum value of $258.45 \mathrm{mg} / \mathrm{L}$ and a maximum of $906.15 \mathrm{mg} / \mathrm{L}$. This value is the starting point for establishing a limit and minimizing the effects of chlorides when discharged into the environment. The reduction of the chloride levels in the soaking effluents, implies for the tanneries to implement source reduction measures, applying the Cleaner Production process focused on minimization and reuse, with the last alternative being to treat the effluent at the end of the process.
It is important to strengthen the present study with a greater number of samples, representative of the national tanneries, to validate the findings of the present investigation. For this purpose, a more indepth study should be carried out to analyze samples of tanning effluents in the main areas where this industry is developed in Peru, which is not only Lima, but also Trujillo and Arequipa, and thus have a national scope. It is suggested that at the legislative level, the maximum permissible limit values for tanning effluents be updated to include a limit value for chlorides based on studies that consider the toxicity of the element, as is the case with the present research, and even promote research that analyzes toxicity with species of different trophic levels.

\section{Acknowledgements}

We aknowledge to the Productive Innovation and Technological Transfer Center of Leather, Footwear and related industries (CITEccal Lima) and all its staff for the support provided to carry out this project.

\section{REFERENCES}

1. Aragón Guzmán, M., Sistema de referenciación ambiental (SIRAC) para el sector curtiembre en Colombia, Proyecto gestión ambiental en la industria de curtiembres, 2004.

2. Emmer, V., del Campo, M.J., Guía de Producción Más Limpia en el Sector Curtiembres, Vol. 53, Dinama, 2014, 1689-1699 p.

3. China Leather and Footwear Industry, Developing countries training course on eco-leather manufacture technology, Beijing, China, 2007.

4. Escoto-Palacios, M.J., Pérez-Limiñana, M.Á., Arán-Ais, F., From leather waste to functional leather, 2016, $60 \mathrm{p}$.

5. Hussain, F., Malik, S.A., Athar, M., Bashir, N., Younis, U., Mahmood-ul-Hassan, Mahmood, S., Effect of tannery effluents on seed germination and growth of two 
sunflower cultivars, African J Biotechnol, 2010, 9, 32, 5113-20.

6. Calheiros, C.S.C., Silva, G., Quitério, P.V.B., Crispim, L.F.C., Brix, H., Moura, S.C., Castro, P.M.L., Toxicity of High Salinity Tannery Wastewater and Effects on Constructed Wetland Plants, Int J Phytoremediation, 2012, 14, 7, 669-80, https://doi.org/10.1 080/15226514.2011.619233.

7. Kohli, R., Malaviya, P., Impact of tannery effluent on germination of various varieties of wheat (Triticum aestivum L.), J Appl Nat Sci, 2013, 5, 2, 302-5, https:// doi.org/10.31018/jans.v5i2.321.

8. Mwinyihija, M., Ecotoxicological Diagnosis in the Tanning Industry [Internet], New York, NY: Springer New York; 2010, 157 p., available from: http://link.springer. com/10.1007/978-1-4419-6266-9, https://doi.org/10.1007/978-1-44196266-9_4.

9. Planes, E., Fuchs, J., Cuáles son los aportes de la ecotoxicología a las regulaciones ambientales, Cienc Invest, 2015, 65, 2, 18.

10. Sobrero, M.C., Ronco, A., Ensayo de toxicidad aguda con semillas de lechuga Lactuca sativa L. Ensayos toxicológicos y métodos de evaluación de calidad de aguas, 2004.

11. OECD, Terrestrial Plants, Growth Test, in: Guidelines for the Testing of Chemicals, 1984, p. 6.

12. Campagna-Fernandes, A.F., Marin, E.B., Penha, T.H.F.L., Application of root growth endpoint in toxicity tests with lettuce (Lactuca sativa), Ecotoxicol Environ Contam, 2016, 11, 1, 27-32, https://doi. org/10.5132/eec.2016.01.05.

13. USEPA, Ecological Effects Test Guidelines OPPTS (850.4200), Seed Germination/ Root Elongation Toxicity Test, United States; 1996, p. 1-8.

14. Sánchez Ortiz, K., Sánchez Melo, L., Determinación De La Concentración De Inhibición Media (Ce50-120) Del Bario, Hierro Y Manganeso Mediante Bioensayos De Toxicidad Acuática Sobre
Semillas De Lechuga (Lactuca Sativa L.) [Internet], Universidad de La Salle; 2009, available from: http://repository.lasalle. edu.co/bitstream/handle/10185/14913/ T41.09 S55de.pdf?sequence=1

15. Sobrero, M.C., Estudio de la fitotoxicidad de metales pesados y del herbicida glifosato en ambientes acuáticos, Bioensayos con plantas vasculares como organismos diagnóstico, Universidad Nacional de La Plata; 2010.

16. Bohórquez-Echeverry, P., CamposPinilla, C., Evaluación de Lactuca sativa Y Selenastrum capricornutum como indicadores de toxicidad en aguas, Univ Sci, 2007, 12, 2, 83-98.

17. Ronco, A.E., Ensayos toxicológicos y métodos de evaluación de calidad de aguas, 2004, $190 \mathrm{p}$.

18. Lyu, J., Park, J., Kumar Pandey, L., Choi, S., Lee, H., De Saeger, J., Depuydt, S., Han, T., Testing the toxicity of metals, phenol, effluents, and receiving waters by root elongation in Lactuca sativa L., Ecotoxicol Environ Saf, 2018, 149 (November 2017), 225-32, https://doi.org/10.1016/j. ecoenv.2017.11.006.

(C) 2020 by the author(s). Published by INCDTPICPI, Bucharest, RO. This is an open access article distributed under the terms and conditions of the Creative Commons Attribution license (http:// creativecommons.org/licenses/by/4.0/). 